\title{
CCL Chemokines Levels in Tear Fluid of Patients with Cystic Fibrosis
}

\author{
Malgorzata Mrugacz \\ Medical University of Bialystok \\ Poland
}

\section{Introduction}

Cystic fibrosis (CF) is inherited as an autosomal recessive disorder in white populations, caused by a mutation in a gene that encodes cystic fibrosis transmembrane conductance regulator (CFTR) protein, which is expressed in many epithelial cells and blood cells. Although CFTR functions mainly as a chloride channel, it has many other regulatory roles, including inhibition of sodium transport through the epithelial sodium channel, regulation of the outwardly rectifying chloride channel, regulation of ATP channels, regulation of intracellular vesicle transport, acidification of intracellular organelles, and inhibition of endogenous calcium-activated chloride channels (O'Sullivan \& Freedman, 2009; Reisin et al., 1994; Schwiebert et al., 1995; Stutts et al., 1995; Vankeerberghen et al., 2002; Mehta, 2005). CFTR is also involved in bicarbonate-chloride exchange. A deficiency in bicarbonate secretion leads to poor solubility and aggregation of luminal mucins (Quinton, 2008). More than 1500 CFTR mutations have been identified, but only the functional importance of a small number is known. The absence of phenylalanine at position 508 accounts for about two-thirds of mutated alleles in northern European and North American populations (Walters \& Mehta, 2007).

The clinical manifestations of the disease vary greatly between affected individuals, which has led to interest in the relation between genotype and phenotype. It is presumed that disease affects all secretory epithelia including the eye (Castagna, 2001; Turner et al., 2002; Mrugacz et al., 2006; Mrugacz et al., 2007; Mrugacz et al., 2007). The pathogenesis of ocular changes in CF is still unknown. CF belongs to the group of ocular surface diseases termed keratoconjunctivitis sicca or dry eye syndrome. The causes of dry eye are multi-factorial and can be connected with deficiencies in any one of the components of the ocular surface and tear fluid. It is known that inflammation plays a key role in the pathogenesis of dry eye (Baudouin, 2001; Brignole et al., 2000; Pflugfelder, 2004; Pisella et al., 2000), especially with the participation of chemokines.

Chemokines are a family of small protein molecules that play an important role in normal leukocyte trafficking as well as in leukocyte recruitment during inflammation. These chemokines are grouped into CXC, CC, C, and CX3C subfamilies on the basis of the arrangement of the conserved cysteine residues. This molecular subvivision generally correlates with their function. Most recently, chemokines have been classified according to 
their physiological features: inflammatory or inducible chemokines and homeostatic or constitutive chemokines. Chemokines act through both specific and shared receptors that belong tho the superfamily of G-protein-coupled receptors. The chemokine receptors also comprise four groups, including the $\mathrm{CC}$ receptors (CCR), which bind CC chemokines; and CXC receptors (CXCR), which bind CXC chemokines. Chemokine and chemokine receptor expression can increase in acute and chronic inflammatory conditions due to inflammatory mediators, such as cytokines. The CC chemokines are involved in the pathogenesis of immune-mediated inflammation through monocytes/macrophages activation and recruitment. CC chemokines, such as CCL3/macrophage inflammatory protein-1a (CCL3/MIP-1a) and CCL4/macrophage inflammatory protein-1ß (CCL4/MIP-1ß) are efficient chemoattractant for Th1 cells and contribute to the inflammatory processes in the eye (Locati \& Murphy, 1999; Manczak \& Yiang, 2002).

The aim of this study was to assess the potential role of chemokines in the pathogenesis of ocular changes in patients with CF. We assayed CCL3/MIP-1a and CCL4/MIP-1ß levels in tear fluid of $\mathrm{CF}$ patients. We also investigated the correlation between the tear levels of these chemokines and clinical severity of CF and ocular surface disease.

\section{Materials and methods}

\subsection{Patients}

We studied 28 patients with CF with a mean age 14.75 \pm 3.95 years (range 6-23) (14 women, 14 men) who attended 3th Department of Pediatric Diseases, Medical University of Bialystok, Poland. Twenty-seven normal subjects with a mean age of $15.21 \pm 4.35$ years (range 8-23) (13 women, 14 men) were also included. All the CF patients had a comprehensive assessment every 6-12 months and were receiving vitamin A supplementation. They did not receive any systemic steroid therapy.

The clinical status was scored according to Schwachmann and Kulczycki (Schwachman Score, scale 100-0: 100=excellent, 100-55=without pulmonary insufficiency, below 55=severe of CF) (Schwachmann \& Kulczycki, 1958).

\subsection{Tear sample collection}

Tear samples were collected in graduated 30- $\mu$ l disposable microcapillaries (ACCU-FILL 90 MICROPET, Becton Dickinson and Company, Franklin Lakes, NJ) unilaterally or bilaterally from the conjunctival cul-de-sac without anesthesia. Care was taken to avoid touching the lid margin or corneal surface. We collected 50 to $100 \mu$ of basal tears from each eye. The CCL3/MIP-1a and CCL4/MIP-1ß levels in tears were determined by ELISA using highly sensitive immunoassay kit (Endogen system, MA, USA). The collected tears were immediately frozen to $-80^{\circ} \mathrm{C}$; they were thawed just before assaying. All the samples were coded and read blind in the assay. The procedure recommended by the manufacturer was followed without any modification.

\subsection{Ophthalmic examination including dry eye tests}

The ophthalmologic examination included subjective assessment, visual acuity and biomicroscopy. Subject complaints, such as redness, foreign body sensation, irritation, intense burning, and blurred vision were noted. Both patients and controls were performed tests for keratoconjunctivitis sicca. Tear break-up time (TBUT) was measured to assess tear 

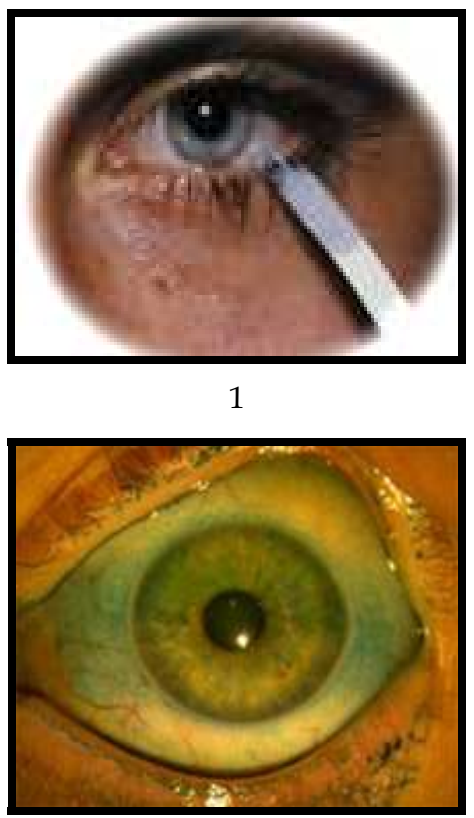

2

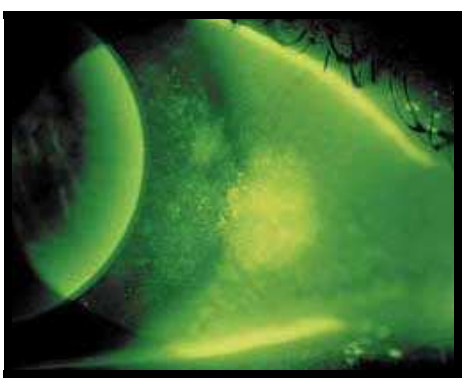

3

Fig. 1. Dry eye tests. 1- Schirmer test, 2- Tear break-up time (TBUT), 3- Lissamine green staining 
film stability. A value of $<10$ seconds was abnormal. Schirmer test was used to estimate tear film quantity; a value of $<5 \mathrm{~mm}$ after 5 minutes was abnormal. The lissamine green instilled into the inferior fornix was used to assess the amount of dead epithelial cells at the ocular surface. If two of these variables were abnormal then dry eye syndrome was the diagnosis according to the Copenhagen criteria (Manthorpe 1986). All clinical examinations were performed before any topical or systemic treatment was administered to the eye.

\subsection{Statistical analysis}

Non- parametric analysis was conducted in this study. Wilcoxon's sum rank test was used to identify differences between tear chemokine levels in patients group and controls. Spearman's rank correlation test was used to establish the significance of correlation between tear chemokine levels and severity of CF and the eye disease. A level of $p<0.05$ was accepted as statistically significant.

\section{Results}

\subsection{Chemokines levels}

The tear fluid levels of CCL3/MIP-1a were $144.50 \pm 18.51 \mathrm{pg} / \mathrm{mL}$ (mean \pm SD) in CF patients, whereas in normal controls, they were $41.85 \pm 11.25 \mathrm{pg} / \mathrm{mL}$ (mean $\pm \mathrm{SD}$ ). There is significant difference between serum levels of MIP-1a in CF patients and healthy controls $(p=0.001)$ The tear fluid levels of CCL4/MIP-1ß were $4.25 \pm 1.15 \mathrm{pg} / \mathrm{mL}$ (mean $\pm \mathrm{SD}$ ) in CF patients and $0.52 \pm 0.36 \mathrm{pg} / \mathrm{mL}($ mean $\pm \mathrm{SD})$ in healthy controls. The tear fluid levels of MIP-1beta were significantly raised in CF group compared to controls $(\mathrm{p}<0.001)$.

\subsection{Assessment of dry eye syndrome}

Dry eye syndrome were observed in 10 (36\%) CF patients (five girls and five boys). However, the tear fluid levels of CCL3/MIP-1a and CCL4/MIP-1ß were significantly higher in CF patients with dry eye syndrome than in CF patients without dry eye symptoms: $165.50 \pm 20.32 \mathrm{pg} / \mathrm{mL}($ mean \pm SD) and $132.22 \pm 17.35 \mathrm{pg} / \mathrm{mL}$ (mean \pm SD) of CCL3/MIP-1a, respectively; and $5.25 \pm 1.26 \mathrm{pg} / \mathrm{mL}($ mean $\pm \mathrm{SD})$ and $3.18 \pm 0.80 \mathrm{pg} / \mathrm{mL}$ (mean $\pm \mathrm{SD}$ ) of CCL4/MIP-1ß, respectively $(\mathrm{p}<0.05)$.

\subsection{Assessment of pulmonary insufficiency}

Symptoms of pulmonary insufficiency (below 55 according to the Schwachman- Kulczycki Score) were found in $45 \%$ (13 out of 28 ) of the CF patients. Spearman correlation coefficient indicated a positive correlation between the tear levels of CCL3/MIP-1a and CCL4/MIP-1ß and severe clinical status of $C F$ patients $(R=0.869, p<0.001)$. However, negative correlation was found between the tear levels of these chemokines and mild $C F(R=-0.817, p<0.001)$. Fifteen of our CF patients (55\%) with high levels of CCL3/MIP-1a and CCL4/MIP-1ß had clinical evidence of dry eye. Spearman correlation coefficient indicated a positive correlation between the tear levels of these chemokines and dry eye findings in CF patients.

\section{Discussion}

One of the major problems in understanding the mechanisms of dry eye symptoms in CF patients, is to determine the factors involved in this disease. It is known that inflammation 
plays a key role in the pathogenesis of dry eye syndrome, especially with the participation of chemokines. Chemokines are expressed at sites of inflammation to attract and amplify the leukocyte response. It is important to identify chemokines that play a role in mediating response. The recruitment of leukocytes to tissue is essential for inflammation. This process may be controlled by MIP-1a and CCL4/MIP-1beta that contribute to the recruitment of inflammatory cells into the eye and plays an important role in pathogenicity.

In this study, we have documented, for the first time, raised levels of CCL3/MIP-1a and CCL4/MIP-1beta in tear fluid in CF patients. The highest levels of these chemokines were detected in patients with dry eye syndrome and severe CF. The high levels of suggest of CCL3/MIP-1a and CCL4/MIP-1beta suggest that these chemokines may be produced locally and may be a factor for evaluation of the clinical status of this disease. It may confirm the involvement of CCL4/MIP-1beta in the local inflammatory process. Functional consequence of elevated levels of these chemokines has yet to be determined exactly. Moreover, there is evidence that dry eye stimulates the production of inflammatory cytokines from the ocular surface epithelium (Luo et al., 2004). The increased levels of MIP$1 \alpha$ and MIP-1beta observed in this study may be a consequence of increased secretion from the corneal epithelium or from the another noncorneal cell type. The tear film containing numerous specific and nonspecific immune components (Solomon et al., 2001) may act as a vehicle of chemokines produced by the lacrimal gland or other epithelia of the ocular surface.

There is a little information about the role of CCL3/MIP-1a and CCL4/ MIP-1beta in eye inflammation. Despite advances in tissue typing, surgery and immunosuppressive treatment allogenic rejection is the most common cause of corneal graft failure. Allograft rejection is characterized by infiltration of leucocytes into the donor tissue, a response that has been associated with chemokine expression, with CCL2/MCP-1, CCL3/ MIP-1a and CCL4/ MIP-1beta showing ans increased expression in rejected grafts in mice (Yamagami et al., 1999). In recent studies of CCL3/MIP-1a and CCL4/ MIP-1B, Verma and others have shown that these chemokines were significantly increased in the aqueous humor during the active stages of human autoimmune anterior uveitis (AAU) and correlated with the clinical severity of the disesase (Verma et al., 1997). Anti-MIP-1a and anti-MIP$1 \mathrm{~B}$ treatment suppressed clinical signs of recurrent anterior uveitis (RAU) in the Lewis rats, suggesting that these chemokines may also influence the migration of memory $\mathrm{T}$ cells across the blood ocular barrier in recurring episode of AAU. In addition, during acute AAU associated with experimental autoimmune encephalomyelitis (EAE), CC chemokines, such as CCL2/MCP-1, CCL5/RANTES, CCL3/MIP-1a and CCL4/MIP-1B, contributed to the inflammatory processes in the eye and central nervous system (CNS) (Manczak et al., 2002). Treatment with anti-CCL4/ MIP-1ß delayed onset and reduced duration of AAU (Adamus et al., 2001). The retinal ischemia- reperfusion model showed an upregulation of CCL4/MIP-1beta in the retinal vessels and these results confirm that this chemokine may be involved in the inflammatory element of pathogenesis of retinal neovascularization (Jo et al., 2003).

\section{Conclusion}

In conclusion, the results of this study demonstrate that increased levels of chemokines in the tear fluid may play an important role in the pathogenesis of dry eye in patients with 
cystic fibrosis. The tear levels of CCL3/MIP-1a and CCL4/MIP-1ß may be a candidate marker to evaluate the clinical status of cystic fibrosis and eye disease. Our findings may contribute to further understanding of local and systemic immune responses and might lead to the development of new clinical approaches to inflammatory disorders. Clarification of the role of chemokines in the pathogenesis of ocular findings in CF patients will be useful in establishing immunotherapeutic strategies for this disease.

\section{Acknowledgment}

I think Prof. Maciej Kaczmarski (3th Department of Pediatrics, Medical University of Bialystok, Poland) and Beata Żelazowska-Rutkowska (Department of Pediatric Laboratory Diagnostic Medical University of Bialystok, Poland) for their assistance.

\section{References}

Adamus, G.; Manczak, M. \& Machnicki, M. (2001). Expression of CC chemokines and their receptors in the eye in autoimmune anterior uveitis associated with EAE. Invest Ophthalmol Vis Sci, 42, pp. 2894-2903, ISSN 1552-5783

Baudouin, C. (2001). The pathology of dry eye. Surv Ophthalmol, 45: pp. 211-20, ISSN 00396257

Brignole, F.; Pisella P.J.; Goldshild, M.; De Saint Jean, M.; Goguel, A. \& Baudouin, C. (2000). Flow cytometric analysis of inflammatory markers in conjunctival epithelial cells of patients with dry eyes. Invest Ophthalmol Vis Sci, 41, pp. 13561363, ISSN 1552-5783

Castagna, I.; Roszkowska, A.M.; Fama, F.; Sinicropi, S. \& Ferreri, G. (2001). The eye in cystic fibrosis. Eur J Ophthalmol, 11, pp. 9-14, 1120-6721

Jo, N.; Wu, G.S. \& Rao, N.A. (2003). Upregulation of chemokine expression in the retinal vasculature in ischemia-reperfusion injury. Invest Ophthalmol Vis Sci, 44, pp. 405460, ISSN 1552-5783

Locati, M. \& Murphy, P. (1999). Chemokines and chemokine receptors: biology and clinical relevance in inflammation and AIDS. Annu Rev Medicine, 50, pp. 425-440, ISSN 0163-7525

Luo, L.; Li, D,Q. \& Doshi, A. (2004). Experimental dry eye stimulates production of inflammatory cytokines and MMP-9 and activates MARK signaling pathways on the ocular surface. Invest Ophthalmol Vis Sci, 45, pp. 4293-4301, ISSN 1552-5783

Manczak, M.; Jiang, A.; Orzechowska, B. \& Adamus, G. (2002). Crucial role of CCL3/MIP$1 a$ in the recurrence of autoimmune anterior uveitis induced with myelin basic protein in Lewis rats. J Autoimmun, 18, pp. 259-270, ISSN 0896-8411

Manthorpe, R.; Oxholm, P. \& Prause JU. (1986). The Copenhagen criteria for Sjogren's syndrome. Scand J Rheumatol (suppl), 61, pp. 19-21, ISSN 0300-9742

Mehta, A. (2005). CFTR: more than just a chloride channel. Pediatr Pulmonol, 39, pp. 292-98, ISSN 1054-187X 
Mrugacz, M.; Kaczmarski, M.; Bakunowicz-Łazarczyk, A.; Żelazowska, B; Wysocka, J. \& Minarowska, A. (2006). IL-8 and IFN-gamma in tear fluid of patients with cystic fibrosis. J Interferon Cytokine Res, 26, pp. 71-5, ISSN 1079-9907

Mrugacz, M.; Żelazowska, B.; Bakunowicz-Łazarczyk, A.; Kaczmarski, M. \& Wysocka, J. 2007. Elevated tear fluid levels of MIP-1a in patients with cystic fibrosis. J Interferon Cytokine Res 27:491-495

Mrugacz M, Żak J, Bakunowicz-Łazarczyk A, Wysocka J, Kaczmarski M. 2007. ICAM-1 expression on conjunctival epithelial cells in patients with cystic fibrosis. Cytometry B Clin Cytom, 72, pp. 204-8, ISSN 1009-3591

O'Sullivan, B.P. \& Freedman, S.D. (2009). Cystic fibrosis. Lancet, 373, pp. 1891-94, ISSN 01406736

Pflugfelder, S.C. (2004). Antiinflammatory therapy for dry eye. Am J Ophthalmol, 137, pp. 337-342, ISSN 1549-4713

Pisella, P.J.; Brignole, F.; Debbasch, C.; Pharm, D.; Lozato, P.A. \& Creuzot-Garcher C. (2000). Flow cytometric analysis of conjunctival epithelium in ocular rosacea and keratoconjunctivitis sicca. Ophthalmology, 107, pp. 1841-1849, ISSN 0301-4738

Quinton, P.M. (2008). Cystic fibrosis: impaired bicarbonate secretion and mucoviscidosis. Lancet, 372, pp. 415-17, ISSN 0140-6736

Reisin, I.L.; Prat, A.G. \& Abraham, E.H. (1994). The cystic fibrosis transmembrane conductance regulator is a dual ATP and chloride channel. J Biol Chem, 269, pp. 20584-91, ISSN 0021-9258

Schwachmann, H. \& Kulczycki, L.L. (1958). Long term study of 105 patients with cystic fibrosis. Studies made over a 5 to 14 year period. Am J Dis Child, 96, pp. 6-15, ISSN 0096-8994

Schwiebert, E.M.; Egan, M.E. \& Hwang, T.H. (1995). CFTR regulates outwardly rectifying chloride channels through an autocrine mechanism involving ATP. Cell, 81, pp. 1063-73, ISSN 0092-8674

Solomon, A.; Dursun, D. \& Liu. Z. (2001). Pro- and anti-inflammatory forms of interleukin-1 in the tear fluid and conjunctiva of patients with dry-eye disease. Invest Ophthalmol Vis Sci , 42, pp. 2283-92, ISSN 1552-5783

Stutts, M.J.; Canessa, C.M. \& Olsen, J.C. (1995). CFTR as a cAMP-dependent regulator of sodium channels. Science, 269, pp. 847-50, ISSN 0036-8075

Turner, H.C.; Bernstein, A. \& Candia, O.A. (2002). Presence of CFTR in the conjunctival epithelium. Curr Eye Res, 24, pp. 182-7, ISSN 0271-3683

Vankeerberghen, A.; Cuppens, H. \& Cassiman, J.J. (2002). The cystic fibrosis transmembrane conductance regulator: an intriguing protein pleiotropic functions. J Cyst Fibros, 1, pp. 13-29, ISSN 8755-6863

Verma, M.J.; Lloyd, A.; Rager, H.; Strieter, R.; Kunkel, S.; Taub, D. \& Wakefield, D. (1997). Chemokine in acute anterior uveitis. Curr Eye Res 16: pp. 1202-1208, ISSN 02713683

Walters, S. \& Mehta, A. (2007). Epidemiology of cystic fibrosis. In: Hodson M, Geddes DM, Bush A, eds. Cystic fibrosis, 3rd ed. London: Edward Arnold Ltd, pp. 21-45, ISBN 10: 0340742089 
Yamagami, S.; Miyazaki, D.; Ono, S.J. \& Dana, M.R. (1999). Differential chemokine gene expression in corneal trans plant rejection. Invest Ophthalmol Vis Sci, 40, pp.28922897, ISSN 1552-5783 


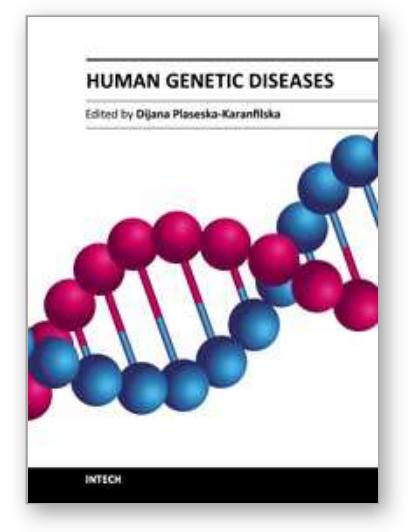

\author{
Human Genetic Diseases \\ Edited by Dr. Dijana Plaseska-Karanfilska
}

ISBN 978-953-307-936-3

Hard cover, 286 pages

Publisher InTech

Published online 30, September, 2011

Published in print edition September, 2011

The genetics science is less than 150 years old, but its accomplishments have been astonishing. Genetics has become an indispensable component of almost all research in modern biology and medicine. Human genetic variation is associated with many, if not all, human diseases and disabilities. Nowadays, studies investigating any biological process, from the molecular level to the population level, use the â€œgenetic approachâ€ to gain understanding of that process. This book contains many diverse chapters, dealing with human genetic diseases, methods to diagnose them, novel approaches to treat them and molecular approaches and concepts to understand them. Although this book does not give a comprehensive overview of human genetic diseases, I believe that the sixteen book chapters will be a valuable resource for researchers and students in different life and medical sciences.

\title{
How to reference
}

In order to correctly reference this scholarly work, feel free to copy and paste the following:

Malgorzata Mrugacz (2011). CCL Chemokines Levels in Tear Fluid of Patients with Cystic Fibrosis, Human Genetic Diseases, Dr. Dijana Plaseska-Karanfilska (Ed.), ISBN: 978-953-307-936-3, InTech, Available from: http://www.intechopen.com/books/human-genetic-diseases/ccl-chemokines-levels-in-tear-fluid-of-patients-withcystic-fibrosis

\section{INTECH}

open science | open minds

\author{
InTech Europe \\ University Campus STeP Ri \\ Slavka Krautzeka 83/A \\ 51000 Rijeka, Croatia \\ Phone: +385 (51) 770447 \\ Fax: +385 (51) 686166 \\ www.intechopen.com
}

\author{
InTech China \\ Unit 405, Office Block, Hotel Equatorial Shanghai \\ No.65, Yan An Road (West), Shanghai, 200040, China \\ 中国上海市延安西路65号上海国际贵都大饭店办公楼 405 单元 \\ Phone: +86-21-62489820 \\ Fax: +86-21-62489821
}


(C) 2011 The Author(s). Licensee IntechOpen. This chapter is distributed under the terms of the Creative Commons Attribution-NonCommercialShareAlike-3.0 License, which permits use, distribution and reproduction for non-commercial purposes, provided the original is properly cited and derivative works building on this content are distributed under the same license. 